\title{
pentecostalismo integrado? A contribuição de Alfonso García Rubio para a superação do dualismo antropológico
}

\author{
Orientador: Joel Portella Amado \\ Mestrando: Bruno da Silveira Albuquerque \\ Área de Concentração: Teologia Sistemático-Pastoral
}

Linha de Pesquisa: Religião e Modernidade

A antropologia teológica busca focalizar o ser humano e suas dimensões a partir da realidade da fé em Jesus Cristo. Com interesse especial nessa busca, nos propomos, dentro de uma ótica sistemático-pastoral, investigar a possibilidade de superação do problema conhecido como dualismo antropológico no interior do movimento pentecostal brasileiro, a partir da caracterização de suas representações mais influentes no cenário nacional atualmente, tanto do chamado pentecostalismo clássico, como do neopentecostalismo. Para a análise de conceituação e identificação do dualismo, e ainda para o critério de assimilação da antropologia teológica de integração, oposta ao dualismo, toma-se como principal referência teórica a obra do teólogo espanhol radicado no Brasil, Alfonso García Rubio, dada a sua relevância e experiência no assunto em questão. Com isto, pretendemos chegar ao fim da pesquisa oferecendo uma perspectiva não somente teórica, mas principalmente prática, para o segmento cristão estudado, a fim de que se perceba sua possibilidade real de superação do dualismo constatado.

Palavras-chave: Ser humano; Fé cristã; Dualismo. 